WW W. TER A P E V T Y K A. C O M. U A

\title{
ДІАГНОСТИЧНІ МОЖЛИВОСТІ ОПИТУВАЛЬНИКА GERDQ НА ОСНОВІ РЕЗУЛЬТАТІВ ДОБОВОГО ЕЗОФАГО-ІМПЕДАНС- pH-МОНТТОРИНГУ
}

\author{
І.Г. Палій, С.В. Заїка, О.О. Ксенчин, Н.С. Скічко
}

Вінницький національний медичний університет ім. М.І. Пирогова

Вступ. На сьогодні залишається актуальним питання використання неінвазивних інструментів рутинної діагностики ГЕРХ, до яких відносяться опитувальники. Найбільш перспективним у цьому плані $є$ опитувальник GerdQ. Мета роботи: вивчити діагностичну цінність опитувальника GerdQ щодо можливостей діагностики ГEPX на основі співставлення результатів опитувальника з результатами добового інтралюмінального езосраго-імпеданс-рН-моніторингу в Україні. Матеріали та методи: 28 пацієнтам після заповнення опитувальника GerdQ було виконано добовий езофраго-імпеданс-рH-моніторинг. Результати інструментального методу діагностики ГЕРХ були співставлені з результатами опитувальника GerdQ. Результати та обговорення: встановлено статистично достовірний кореляційний зв'язок високої сили між частотою епізодів кислих рефрлюксів (pH <4) та сумою балів опитувальника GerdQ - 0,796, частотою епізодів усіх рідинних рефрлюксів та сумою балів опитувальника GerdQ $-0,730$, відсотком часу з $\mathrm{pH}<4$ у стравоході та сумою балів опитувальника GerdQ - 0,793. Відповідно до аналізу ROC-кривої, найкращою точкою відсічення є сумарний бал >7. Чутливість опитувальника становила 78,7\% (95\% Cl, 49-95), специсічність — 92,9\% (95\% Cl, 6699). $A U C=0,95 \pm 0,04 ; p<0,0001$. Відповідно до характеристики класифікації моделей, модель з AUC (площею під ROC-кривою) більше 0,9 характеризується як відмінна модель. Висновки: оптимальним є використання опитувальника GerdQ для діагностики ГЕРХ лікарями первинної ланки в повсякденній практиці для прийняття рішення щодо можливості призначення терапії «ex juvantibus» або необхідності застосування інструментальних методів обстеження (верхня ендоскопія, езофаго-рН-моніторинг, езофаго-імпеданс-рН-моніторинг), оскільки він показав достовірний, високий ступінь кореляції між сумою балів опитувальника та ключовими показниками добового імпеданс-рН-моніторингу (епізоди кислих рефрлюксів, епізоди рідинних рефрлюксів, відсоток часу з рН у стравоході <4).

Ключові слова: гастроезофрагеальна ресрлюксна хвороба, опитувальники, добовий езораго-імпеданс-рH-моніторинг, опитувальник GerdQ.

DOI: 10.31793/2709-7404.2021.2-2.21

(ㅇ І.Г. Палій, С.В. Заїка, О.О. Ксенчин, Н.С. Скічко

Надійшла до редакції 03.03.2021

Адреса для листування

(Correspondence): Вінницький національний медичний університет ім. М.І. Пирогова, вул. Пирогова, 56, м. Вінниця, 21018, Україна. E-mail: vinshura@gmail.com 


\title{
Diagnostic capabilities of the GerdQ questionnaire based on the results of 24-hour esophageal- impedance-pH monitoring
}

\author{
I.G. Paliy, S.V. Zaika, 0.0. Ksenchyn, N.S. Skichko \\ National Pirogov Memorial Medical University, Vinnytsya
}

\begin{abstract}
Introduction. At present, the use of non-invasive tools for routine diagnosis of GERD, which include questionnaires, remains relevant. The most promising in this regard is the GerdQ questionnaire. Purpose: to study the diagnostic value of the GerdQ questionnaire on the possibilities of diagnosing GERD based on the comparison of the results of the questionnaire with the results of 24-hour intraluminal esophageal-impedance-pH monitoring in Ukraine. Materials and methods: 28 patients underwent 24-hours esophageal-impedance-pH monitoring after completing the GerdQ questionnaire. The results of the instrumental method for the diagnosis of GERD were compared with the results of the GerdQ questionnaire. Results and discussion: a statistically significant correlation of high strength between the frequency of acid reflux episodes $(\mathrm{pH}<4)$ and the sum of GerdQ questionnaire scores - 0.796, the episode frequency of all liquid refluxes and the sum of GerdQ questionnaire scores 0.730 , the percentage of time with $4 p$ in the esophagus and the sum of the scores of the GerdQ questionnaire - 0.793. According to the analysis of the ROC curve, the best cut-off point is a total score $>7$. The sensitivity of the questionnaire was $78.7 \%(95 \% \mathrm{Cl}$, 49-95), specificity - 92.9\% (95\% Cl, 66-99). AUC=0.95 $\pm 0.04 ; p<0.0001$. According to the model classification characteristics, a model with an AUC (area under the ROC curve) greater than 0.9 is characterized as an excellent model. Conclusions: it is optimal to use the GerdQ questionnaire for the diagnosis of GERD by primary care physicians in everyday practice to decide on the possibility of prescribing therapy «ex juvantibus», or the need for instrumental methods of examination (upper endoscopy, esophago-pH-monitoring, esophago-p- monitoring), as it showed a reliable, high degree of correlation between the sum of the questionnaire scores and key indicators of daily impedance-pH monitoring (episodes of acid reflux, episodes of liquid reflux, \% time with $\mathrm{pH}$ in the esophagus <4).
\end{abstract}

Keywords: gastroesophageal reflux disease, questionnaires, 24-hour esophageal-impedance$\mathrm{pH}$ monitoring, GerdQ questionnaire.

\section{Вступ}

Останнім часом все більша увага лікарів, дослідників приділяється такому захворюванню, як гастроезофагеальна рефлюксна хвороба (ГЕРХ). У різних країнах опубліковано велику кількість практичних рекомендацій та керівництв із діагностики та лікування ГЕРХ [1-4].

Стандартом для діагностики цього захворювання є проведення верхньої ендоскопії та езофаго-рН-моніторингу [5], з часом до них приєднався езосаго-імпеданс-рН-моніторинг як найбільш чутливий метод дослідження, оскільки дозволяє ідентифрікувати не лише кислотні, а й слабкокислотні та газові ресрлюкси, що також відіграють певну роль у виникненні симптоматики ГЕРХ [6-8]. Однак вищезазначені методи діагностики є коштовними, інвазивними та важко переносяться хворими, що ускладнює їх використання в рутинній практичній діяльності при обстеженні пацієнтів із симптомами ГЕРХ.

Для стандартизації визначення ГЕРХ, симптомів, діагностики та підходів до лікування була створена Міжнародна група з консенсусу ГЕРХ, перед якою було поставлено завдання розробити глобальне визначення та основні поняття, що стосуються ГЕРХ. Робота цієї групи тривала 2 роки, і результати її викладені в Монреальському консенсусі у 2006 році. Експертами було визнано можливим встановлювати діагноз ГЕРХ та призначати лікування без результатів додаткових обстежень, базуючись на характерних клінічних симптомах (як стравохідних, так і позастравохідних). Необхідність додаткових методів обстежень (верхня ендоскопія, рH- та імпеданс-рН-моніторинг) визначає сам лікар залежно від вираженості скарг та наявності симптомів «тривоги» [9]. 
Аналогічний алгоритм діагностики ГЕРХ представлений і в трьохрівневому Гштадському керівництві (2008), де на першому рівні можливе самостійне купірування типових симптомів лікарськими засобами. Якщо печія та регургітація виникає частіше ніж 2 рази на тиждень, необхідно звернутись до сімейного лікаря або терапевта, який проводить загальноклінічне обстеження без застосування додаткових методів обстежень. За наявності нетипових симптомів, симптомів «тривоги» або при неефективності лікування пацієнт скеровується на третій рівень до гастроентеролога, який розглядає доцільність додаткових методів обстежень та оптимізацію лікування [10].

Однак такий підхід супроводжується певними складнощами, що пов'язані із суб'єктивною оцінкою скарг як самим пацієнтом, так і лікарем. Адже в повсякденній практиці трапляються хворі зі значними змінами слизової оболонки стравоходу, проте з невираженими симптомами, або пацієнт не знає про можливі ускладнення та не приділяє необхідної уваги своєму стану $[11,12]$. І навпаки, іноді лікар, спираючись лише на дані симптоматики, може неправильно інтерпретувати важкість перебігу захворювання та припускатися діагностичних помилок $[11,13]$. Цьому сприяють поєднання класичної симптоматики ГЕРХ із симптомами шлункової диспепсії, синдромом роздратованої товстої кишки й слабка кореляція між даними ендоскопічної картини та вираженістю симптомів.

Все вищевикладене потребує розробки точної та об'єктивної діагностичної методики, яка була б неінвазивною та можливою до використання в повсякденній практиці як лікарями-гастроентерологами, так і лікарями первинної ланки (лікарями загальної практики - сімейної медицини та терапевтами). Найбільш прийнятним варіантом такої методики $€$ анкети-опитувальники. Слід зазначити, що такі опитувальники мають бути, з одного боку, чутливими та специфічними, а 3 іншого короткими та простими в заповненні, щоб не викликати проблем у пацієнта при їх заповненні.

Розроблено велику кількість опитувальників для діагностики ГЕРХ, проте в більшості своїй вони використовуються для наукових досліджень. Серед таких, що можуть бути широко використані й використовуються в практичній діяльності, є: GSRS (Gastrointestinal Symptom Rating Scale), GSFQ (Gastrointestinal Short Form Questionnaire) [14], CDQ (CarlssonDent Questionnaire), GerdQ. Для забезпечення використання даних опитувальників вони мають бути перекладені та валідизовані. Валідність це комплексна характеристика методики (тесту), що відбиває інформацію про коло досліджуваних явищ, а також міру репрезентативності процедури дослідження щодо них, у спрощеному й узагальненому формулюванні валідність тесту - це «поняття, яке вказує на те, що тест вимірює і наскільки добре він це робить» [15].

Так, у Леонському консенсусі щодо сучасної діагностики ГЕРХ 2018 року розглядається можливість використання в клінічній практиці опитувальників для діагностики ГЕРХ на основі оцінки наявності та частоти типових проявів, таких як печія та регургітація. Відначається, що ці інструменти мають певні обмеження порівняно з інструментальною діагностикою ГЕРХ, проте в клінічній практиці діагностика та лікування ГЕРХ на основі типових симптомів $€$ прагматичними та затвердженими суспільними рекомендаціями. Серед таких рекомендуються опитувальники CDQ та GerdQ як такі, що мають аналогічну діагностичну цінність [16].

Опитувальник GerdQ (Gastroesophageal Reflux Disease Questionnaire) обраний нами для дослідження як найбільш перспективний (рис. 1), оскільки створений на основі трьох інших статистично обгрунтованих опитувальників для оцінки саме рефлюксного синдрому (GIS, GSRS, RDQ) у результаті великого міжнародного дослідження DIAMOND [17]. Метою цього дослідження було створення опитувальника та доведення його діагностичної цінності шляхом порівняння з результатами інструментальних обстежень (верхня ендоскопія та рН-моніторинг). Цей опитувальник показав свою ефективність у багатьох дослідженнях [18-20]. У 2013 році був перекладений російською мовою та валідизований для використання [21].

Як вже було зазначено, оцінка інсрормативності цих опитувальників проводилась шляхом порівняння 3 даними добового езофаго-рН-моніторингу та/або результатами верхньої ендоскопії [19, 20, 22-27], однак не проводилось порівняння з результатами добового езофаго-імпеданс-рН-моніторингу, що дозволяє ідентифрікувати некислотний та газовий рефлюкс і на сьогодні є одним із кращих та найінформативніших інструментальних методів діагностики наявності патологічного гастроезофагеального рефлюксу.

Мета дослідження - вивчення діагностичної цінності опитувальника GerdQ щодо можливостей діагностики ГЕРХ на основі 
співставлення результатів опитувальника з результатами добового інтралюмінального езофраго-імпеданс-рН-моніторингу в Україні.

\section{Матеріали та методи}

У дослідженні брали участь 28 пацієнтів (11 чоловіків та 17 жінок, середній вік -

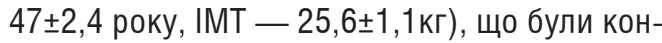
сультовані на кафедрі внутрішньої та сімейної медицини ВНМУ ім. М.І. Пирогова. У нього не включалися пацієнти, які мали пептичну виразку, перенесли резекцію шлунка, мали синдром Золлінгера - Еллісона, неспецифрічний виразковий коліт та хворобу Крона в активній фазі, хронічну серцеву недостатність вище ІІІФК за NYHA, хронічні захворювання нирок із ШКФ $<30$ мл/Хв, легеневу недостатність вище ІІ ст., явища печінкової енцесралопатії вище ІІ ст., портальної гіпертензії II-IV ст. за Baveno. За тиждень до обстеження відмінялись блокатори секреції хлористоводневої кислоти, якщо такі мали місце.

Усі пацієнти після пояснення та підписання письмової згоди на участь у дослідженні самостійно заповнювали опитувальник GerdQ, що містив питання про їхнє самопочуття протягом останніх 7 днів. Під час опрацювання опитувальника GerdQ вивчався як загальний бал опитувальника, так і окрема бальна оцінка по кожному 36 питань: наявність та частота виникнення печії, регургітації, болю в епігастрії, нудоти, виникнення печії вночі та епізоди вживання ліків для усунення печії.

\section{Рисунок 1}

Опитувальник GerdQ

\section{Питання, що стосуються останніх 7 днів}

Як часто Ви відчували печію (печіння за грудниною)?

Як часто Ви відчували потрапляння їжі зі шлунка в глотку або порожнину рота (регургітація)?

Як часто Ви відчували біль у верхній частині живота?

\section{Як часто Ви відчували нудоту?}

Як часто печія та/або регургітація заважали Вам добре виспатись вночі?

Як часто з приводу печії та/або регургітації Ви додатково приймали інші препарати (розчин питної соди, Ренні, Фосфралюгель, Гавіскон...), крім рекомендованих лікуючим лікарем?
За результатами опитувальника GerdQ, нами виявлено 12 пацієнтів, у яких було $\geq 8$ балів, що дозволило запідозрити ГЕРХ, та 16 пацієнтів, у яких було <8 балів, що виключало наявність ГЕРХ у них.

У подальшому всім хворим було виконано добовий мультиканальний інтралюмінальний езофраго-імпеданс-рН-моніторинг. У дослідженні використовувалась комп'ютерна система імпеданс-рН-моніторингу «Ацидогастрограср АГ-3pH-4R», що розроблена медико-інженерним колективом кафредри внутрішньої та сімейної медицини Вінницького національного медичного університету, в умовах міждисциплінарної клініко-діагностичної гастроентерологічної лабораторії, під керівництвом проср. Чернобрового В.М. Мікрозонд-електрод, що використовувався в цьому дослідженні, мав у своєму складі датчик реєстрації рН та 6 датчиків реєстрації імпедансу (рис. 2). Мікрозонд розташовувався трансназально (після градуювання датчика рН у трьох стандарт-титрах з H - 1,68; 4,01 та 6,86) так, щоб датчик pH знаходився в стравоході на 5 см вище від нижнього стравохідного сфрінктера (НCC), у цей час датчики імпедансу утворювали 4 сегменти реєстрації (3, 5, 7 та 12 см вище від НСС).

Результати добового езофаго-імпеданс-рН-моніторингу оцінювались таким чином:

- кількість епізодів кислих ресрлюксів $(\mathrm{pH}<4)$;

- кількість епізодів слабкокислих рефлюксів (pH 4-7);

- кількість епізодів лужних рефлюксів $(\mathrm{pH}>7)$;

\section{Рисунок 2}

Схема розташування зонда та сенсорів на ньому

$\begin{array}{cccc}\text { 0 днів } & \text { 1 день } & \text { 2-3 дні } & \text { 4-7 днів } \\ 0 & 1 & 2 & 3 \\ 0 & 1 & 2 & 3 \\ 3 & 2 & 1 & 0 \\ 3 & 2 & 1 & 0 \\ 0 & 1 & 2 & 3 \\ 0 & 1 & 2 & 3 \\ & & & \end{array}$

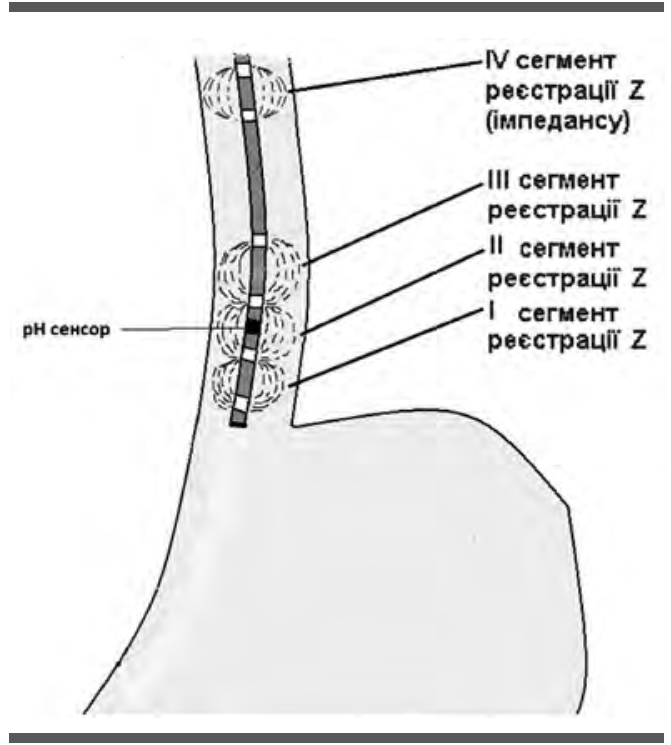




\section{Рисунок 3}

Фрагмент графічного запису добового езофаго-імпеданс-рН-моніторингу пацієнтки X. (на цьому фрагменті виділено епізод кислотного гастроезофагеального рефрлюксу)

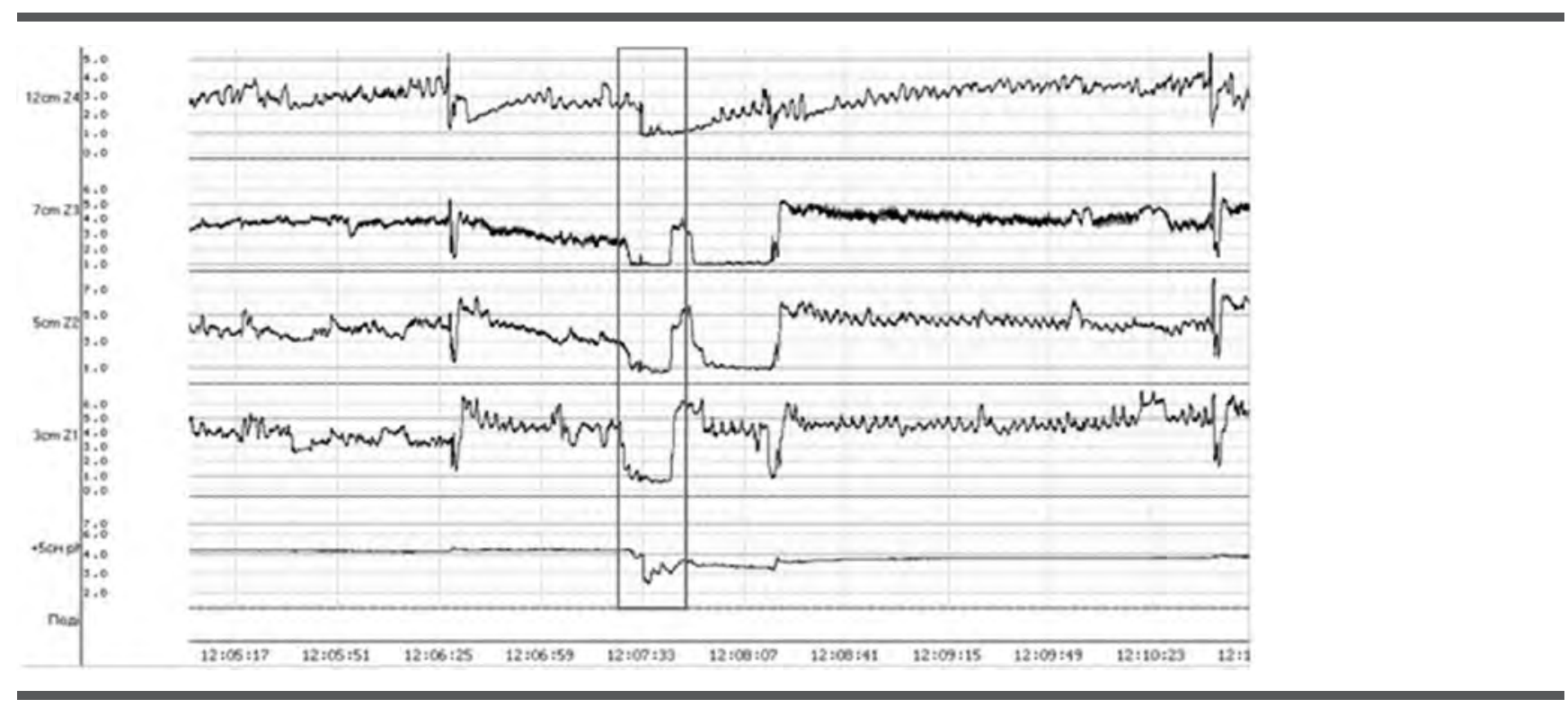

- к кількість епізодів газових рефлюксів;

- кількість епізодів рідинних рефлюксів;

- кількість епізодів змішаних рефлюксів (газ + рідина);

- кількість епізодів кислих ресрлюксів тривалістю більше ніж 5 хвилин;

- $\quad$ загальний час із рН у стравоході <4;

- $\quad$ загальний час із рН у стравоході >7.

Результати дослідження викладались у графічних та цифрових висновках (рис. 3).

Статистичні обрахунки проводились за допомогою комп'ютерної програми Statistica 7.0 Copyright $^{\circledR}$ StatSoft, Inc з обрахуванням середніх значень, стандартних відхилень, стандартних похибок середнього значення, достовірності відмінностей та коефіцієнта рангової кореляції Спірмена. Для вибору оптимального порогового значення діагностичного методу 3 метою класифікації обстежених проводили аналіз ROC-кривих (Receiver Operator Characteristic). Також за допомогою ROC-аналізу проводили визначення чутливості та специфічності методу діагностики.

\section{Результати та обговорення}

Результати опитувальника GerdQ та показники добового езофаго-імпеданс-рН-моніторингу. Нами було проведено оцінку кореляційного зв'язку між показниками добового езофаго-імпеданс-рН-моніторингу та загальним балом опитувальника GerdQ. Згідно з отриманими даними, статистично достовірний кореляційний зв'язок високої сили встановлено між частотою епізодів кислих рефлюксів ( $\mathrm{pH}<4)$ та сумою балів опитувальника GerdQ - 0,796, частотою епізодів усіх рідинних реслюксів та сумою балів опитувальника GerdQ - 0,730, відсотком часу з рH <4 у стравоході та сумою балів опитувальника GerdQ - 0,793. Дані наведено в табл. 1.

Загальний бал GerdQ та результати добового імпеданс-рН-моніторингу. За результатами опитувальника GerdQ, хворі були розділені на 2 групи: група з ГЕРХ, за результатами GerdQ (сума балів $\geq 8$ ), становила 12 пацієнтів та група практично здорових, за результатами GerdQ (сума балів <8), - 16 пацієнтів. Була

\section{Таблиця 1}

Кореляційний зв'язок між результатами добового езофаго-імпедансpH-моніторингу та даними опитувальника GerdQ

\begin{tabular}{ll} 
Показники добового імпеданс-рH-моніторингу & Сума балів згідно з GerdQ \\
Кислі ресллюкси & $0,795^{\star}$ \\
Слабкокислі ресрлюкси & 0,065 \\
Лужні рефрлюкси & 0,032 \\
Газові ресрлюкси & $-0,162$ \\
Рідинні ресрлюкси & $0,730^{*}$ \\
Змішані рефлюкси & 0,106 \\
Кислі ресрлюкси тривалістю >5 хв & 0,375 \\
Час із рН <4 & $0,793^{*}$ \\
Час із рН >7 & $-0,306$ \\
\hline
\end{tabular}

Примітка: * - статистично достовірний кореляційний зв'язок $(p<0,05)$. 
вивчена достовірність відмінностей (t-критерій Стьюдента) показників добового езофраго-імпеданс-рН-моніторингу між цими групами (табл. 2).

У результаті статистично достовірна відмінність $(p<0,05)$ встановлена між середніми значеннями кислих рефлюксів $(55,38 \pm 6,12$ у групі з ГЕРХ проти 23,29ะ6,53 в групі практично здорових осіб згідно з опитувальником GerdQ), газових рефлюксів $(1,46 \pm 0,43$ проти 3,46 0 ,86 відповідно), загальної кількості рідинних ресрлюксів

\section{Таблиця 2}

Середні значення показників добового езофраго-імпеданс-рНмоніторингу в групах хворих

\begin{tabular}{lll}
$\begin{array}{l}\text { Показники добового імпеданс-рH- } \\
\text { моніторингу }\end{array}$ & $\begin{array}{l}\text { ГЕРХ } \\
\text { (згідно з GerdQ) } \\
\geq 8 \text { балів }\end{array}$ & $\begin{array}{l}\text { Практично здорові } \\
\text { (згідно 3 GerdQ) } \\
<\mathbf{8} \text { балів }\end{array}$ \\
\hline Кислі ресрлюкси & $55,38 \pm 6,12^{*}$ & $23,29 \pm 6,53^{*}$ \\
Слабкокислі ресрлюкси & $19,5 \pm 5,15$ & $23,50 \pm 3,02$ \\
Лужні рефрлюкси & $3,69 \pm 1,41$ & $3,93 \pm 1,4$ \\
Газові рефрлюкси & $1,46 \pm 0,43^{*}$ & $3,46 \pm 0,86^{*}$ \\
Рідинні ресрлюкси & $71,15 \pm 8,37^{*}$ & $33,8 \pm 5,97^{*}$ \\
Змішані ресрлюкси & $13,15 \pm 3,73$ & $16,08 \pm 3,57$ \\
Кислі ресрлюкси тривалістю >5 хв & $3,46 \pm 0,80$ & $3,14 \pm 1,38$ \\
Час із рН <4 & $12,42 \pm 3,65^{*}$ & $3,00 \pm 0,92^{*}$ \\
Час із рН >7 & $12,13 \pm 5,60^{*}$ & $31,5 \pm 5,43^{*}$
\end{tabular}

Примітка: * — статистично достовірна відмінність $(p<0,05)$.

\section{Таблиця 3}

Кореляційний зв'язок між результатами добового езофаго-імпедансpH-моніторингу та даними опитувальника GerdQ

\begin{tabular}{|c|c|c|c|c|c|c|}
\hline $\begin{array}{l}\text { Показники } \\
\text { добового } \\
\text { імпеданс-рН- } \\
\text { моніторингу }\end{array}$ & Печія & $\begin{array}{l}\text { Регургі- } \\
\text { тація }\end{array}$ & $\begin{array}{l}\text { Епіга- } \\
\text { страль- } \\
\text { ний } \\
\text { біль }\end{array}$ & Нудота & $\begin{array}{l}\text { Нічні } \\
\text { епізоди } \\
\text { печії }\end{array}$ & $\begin{array}{l}\text { Вживання } \\
\text { ліків для } \\
\text { усунення } \\
\text { печії та } \\
\text { регургі- } \\
\text { тації }\end{array}$ \\
\hline Кислі рефрлюкси & $0,659^{*}$ & $0,655^{\star}$ & $0,556^{*}$ & $0,406^{*}$ & $0,550^{*}$ & 0,110 \\
\hline $\begin{array}{l}\text { Слабкокислі } \\
\text { ресрлюкси }\end{array}$ & 0,143 & 0,140 & 0,076 & 0,201 & 0,021 & 0,158 \\
\hline Лужні ресрлюкси & 0,087 & 0,189 & $-0,192$ & 0,166 & 0,148 & 0,077 \\
\hline Газові ресрлюкси & $-0,103$ & $-0,097$ & 0,129 & $-0,050$ & 0,034 & $-0,123$ \\
\hline Рідинні рефлюкси & $0,497^{*}$ & $0,663^{*}$ & $0,441^{*}$ & $0,405^{\star}$ & $0,481^{*}$ & 0,290 \\
\hline Змішані ресрлюкси & 0,288 & 0,020 & 0,002 & 0,280 & 0,070 & 0,111 \\
\hline $\begin{array}{l}\text { Кислі рефрюкси } \\
\text { тривалістю >5 хв }\end{array}$ & 0,337 & 0,073 & 0,233 & $0,572^{*}$ & 0,316 & $-0,067$ \\
\hline Час із $\mathrm{pH}<4$ & $0,742^{*}$ & $0,505^{\star}$ & $0,566^{\star}$ & $0,399^{*}$ & $0,508^{*}$ & 0,145 \\
\hline Час із $\mathrm{pH}>7$ & $-0,163$ & $-0,188$ & $-0,099$ & $-0,088$ & 0,076 & $-0,028$ \\
\hline
\end{tabular}

Примітка: * - статистично достовірний кореляційний зв'язок $(p<0,05)$.
(71,15 $\pm 8,37$ проти 33,8 $\pm 5,97)$, відсотка часу з рН $<4$ в стравоході (12,42 $\pm 3,65$ проти 3,00 $\pm 0,92$ відповідно) та відсотка часу з $\mathrm{pH}>7$ в стравоході (12,13 27,42 проти $31,5 \pm 5,43$ відповідно).

Водночас ми не встановили відмінностей $(\mathrm{p}<0,05)$ між середніми значеннями слабкокислих ресрлюксів $(19,5 \pm 5,15$ у групі 3 ГЕРХ проти 23,50ะ3,02 в групі практично здорових осіб згідно з опитувальником GerdQ), лужних ресрлюксів $(3,69 \pm 1,41$ проти $3,93 \pm 1,4$ відповідно), змішаних ресрлюксів (13,15 $\pm 3,73$ проти 16,08 $\pm 3,57$ відповідно) та кількості тривалих рефрлюксів $(3,46 \pm 0,80$ проти 3,14 1,38 відповідно).

Оцінка окремих питань GerdQ та результати добового імпеданс-рН-моніторингу. Також ми намагались визначити питання опитувальника GerdQ, що були б чутливими до певних показників езофаго-імпеданс-рН-моніторингу. Для цього провели визначення коефріцієнта кореляції між відповідями пацієнтів на кожне 3 шести питань опитувальника GerdQ та показниками добового езофаго-імпеданс-рН-моніторингу. Статистично достовірний кореляційний зв'язок високої сили встановлено між відсотком часу $3 \mathrm{pH}<4$ в стравоході та частотою виникнення печії $(0,74)$. Кореляційний зв'язок середньої сили - між кількістю кислих рефрлюксів та частотою виникнення печії $(0,66)$, регургітації $(0,66)$, епігастрального болю $(0,56)$, нічних епізодів печії $(0,55)$; між загальною кількістю рідинних рефлюксів та частотою виникнення печії $(0,50)$, регургітації $(0,66)$; кількістю тривалих кислих ресрлюксів (>5 хв) та частотою виникнення нудоти $(0,57)$; між відсотком часу $3 \mathrm{pH}<4$ у стравоході та частотою виникнення регургітації $(0,51)$, епігастрального болю $(0,57)$, нічних епізодів печії $(0,51)$. Слабкий кореляційний зв'язок встановлено між кількістю кислих рефлюксів та частотою виникнення нудоти $(0,41)$; загальною кількістю рідинних рефрлюксів та частотою виникнення епігастрального болю $(0,44)$, нудоти $(0,41)$ та нічних епізодів печії $(0,48)$; між відсотком часу з $\mathrm{pH}<4$ у стравоході та частотою виникнення нудоти $(0,40)$. Інші показники не показали статистично достовірного зв'язку (див. табл. 3).

Чутливість та специфічність опитувальника GerdQ. Оскільки найвищі значення кореляційного зв'язку з показниками добового езофраго-імпеданс-рН-моніторингу показав саме сумарний бал опитувальника GerdQ, ми провели логіт-регресійний аналіз, що дало можливість передбачити ймовірність виникнення досліджуваної події (наявності ГЕРХ) залежно 
від сумарного бала GerdQ за допомогою логістичної функції.

Отримані нами змінні та їх характеристики для рівняння логіт-регресії наведено в табл. 4.

Таким чином, вірогідність наявності ГЕРХ розраховується за формулою:

$$
p=\frac{1}{1+e^{-z}}
$$

де $z=a+b \times x$;

а — константа $(-14,98)$;

b - коесріцієнт $(2,05)$;

X - сума балів GerdQ.

Отже, $z=-14,98+2,05 \times x$.

3 метою оцінки діагностичної здатності опитувальника GerdQ нами були розраховані чутливість та специфічність даного діагностичного методу за допомогою ROC-аналізу. Відповідно до аналізу ROC-кривої, найкращою точкою відсічення $є$ сумарний бал $>7$. Чутливість опитувальника становила 78,7\% (95\% $\mathrm{Cl}, 49-95)$, специфічність - 92,9\% $(95 \% \mathrm{Cl}$, 66-99). $A U C=0,95 \pm 0,04 ; p<0,0001$. Відповідно до характеристики класифікації моделей, модель з AUC (площею під ROC-кривою) більше 0,9 характеризується як відмінна модель. ROC-криву наведено на рис. 4.

Обговорення: висока сила кореляційного зв'язку між сумою балів опитувальника GerdQ та ключовими показниками добового імпеданс-рН-моніторингу свідчить про достатню чутливість цього опитувальника щодо наявності патологічного кислого та рідинного рефлюксів, а також щодо перевищення ліміту часу $3 \mathrm{pH}$ у стравоході <4, що дозволяє рекомендувати використання його для рутинної діагностики ГЕРХ на етапі первинної ланки. Кореляція між окремими питаннями анкети та даними добового езофаго-імпеданс-рН-моніторингу має нижчу силу зв'язку, ніж сума балів опитувальника GerdQ, що свідчить про вищу інформативність саме сумарного бала опитувальника при використанні його з метою діагностики ГЕРХ.

Результати нашого дослідження схожі на ті, що були зафіксовані у валідизаціях та базових оцінках GerdQ в інших популяціях. Наприклад, у початковому дослідженні, де було розроблено анкету ( $n=308$ суб'єктів), бал $\geq 8$ показав чутливість та специфічність 64,6 і 71,4\% відповідно [17]. У дослідженні Lacy et al. [22], де порівняння анкети проводилось із 24-годинним pH-моніторингом за допомогою капсули Bravo, чутливість та специфічність становили 71 та 41\% відповідно. Такі низькі показники, імовірно, пов'язані з тим, що дослідження проводилось на третинному рівні, де великий відсоток пацієнтів

\section{Таблиця 4}

Дані логіт-регресійного аналізу сумарного бала GerdQ з наявністю патологічного гастроезофагеального рефлюксу у хворих на ГЕРХ та осіб без ГЕРХ $(\mathrm{n}=28)$

\begin{tabular}{llllll}
\hline Змінна величина & Коесіцієнт SE & p & $\begin{array}{l}\text { 3начення } \\
\text { відношень } \\
\text { шансів }\end{array}$ & 95\% ДІ \\
\hline $\begin{array}{l}\text { Сума балів GerdQ } \\
\text { Константа }-14,98\end{array}$ & 0,98 & 0,004 & 7,79 & $1,1361-53,3637$ \\
Відсоток правильно класифрікованих випадків $=85,71 \%$ & \\
Перевірка нульової гіпотези: $\chi^{2}=24,293 ;$ DF=1; $p<0,0001$ & \\
\hline
\end{tabular}

\section{Рисунок 4}

ROC-крива аналізу діагностичної здатності опитувальника GerdQ у хворих на ГЕРХ та осіб без ГЕРХ

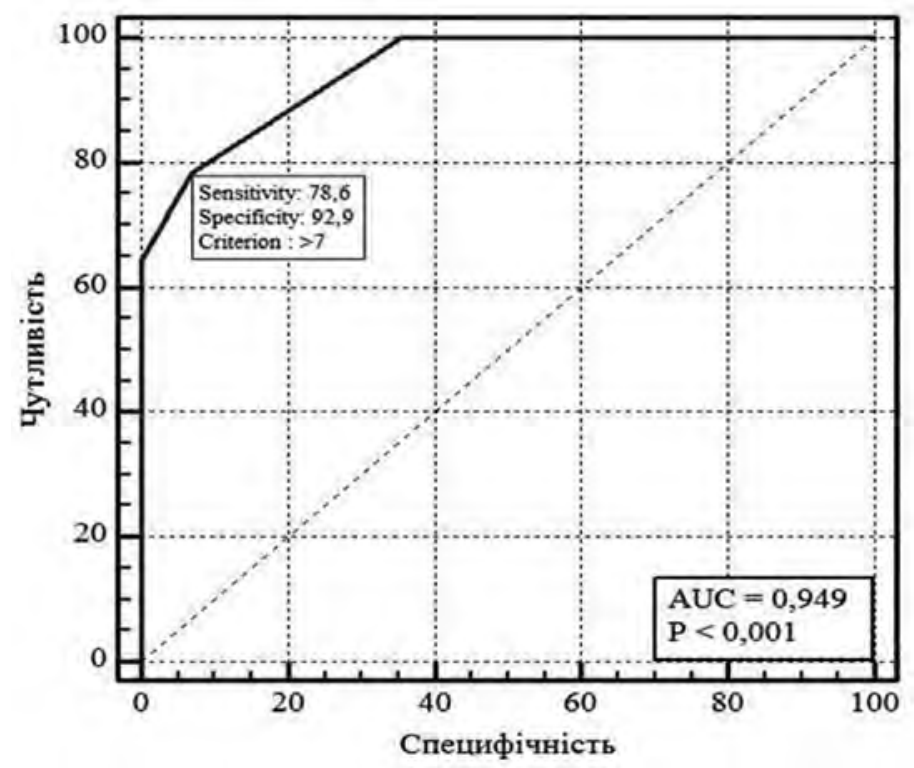

із рефрактерною ГЕРХ, пацієнтів з атиповим перебігом ГЕРХ та пацієнтів із функціональною печією. Результати дослідження Suzuki та співавт. вказують чутливість опитувальника GerdQ $34,3 \%$, а специсрічність - 82,5\% при порівнянні результатів із результатами верхньої ендоскопії. У дослідженні Zavala-Gonzales та співавт. [25] порівняння результатів опитувальника проводили з ендоскопією та/або рН-моніторингом стравоходу, де чутливість та специфічність GerdQ становили 71,6 та 72,2\% відповідно. Результати багатоцентрового дослідження в Росії показали чутливість 65,4\% та специфічність $91,7 \%$, у цьому дослідженні як порівняльні методики використовували верхню ендоскопію та рН-моніторинг [21]. Дещо вищі показники чутливості та специфічності GerdQ в нашому дослідженні порівняно зі схожими дослідженнями 
пов'язані, на нашу думку, з тим, що порівняння результатів опитувальника проводилось саме 3 імпеданс-рН-моніторингом стравоходу, що дає більш точну оцінку патологічного ГЕР, та відносно невеликою кількістю пацієнтів, включених у дослідження.

Нарешті, важливо зазначити, що, хоча GerdQ представляє корисний діагностичний інструмент, це не слід розглядати як унікальний діагностичний тест. Він може бути використаний як базовий тест за відсутності симптомів тривоги. Також він може бути використаний для контролю терапевтичного ефекту лікування ГЕРХ, однак у випадку відсутності відповіді на лікування є необхідним підтвердити діагноз ГЕРХ за допомогою імпеданс-рН-моніторингу та/або ендоскопії відповідно.

\section{Висновки}

На підставі наведеного вище можна зробити такі висновки:

1. Використання опитувальника GerdQ для діагностики ГЕРХ лікарями первинної ланки в повсякденній практиці є найбільш оптимальним для прийняття рішення щодо можливості призначення терапії «ех juvantibus» або необхідності застосування інструментальних методів обстеження (верхня ендоскопія, езофраго-рН-моніторинг, езофаго-імпеданс-рН-моніторинг), оскільки він показав достовірний, високий ступінь кореляції між сумою балів опитувальника та ключовими показниками добового імпеданс-рН-моніторингу (епізоди кислих ресрлюксів, епізоди рідинних реслюксів, відсоток часу з рН у стравоході <4).

2. Кореляційний зв'язок між бальною оцінкою окремих симптомів опитувальника GerdQ та даними імпеданс-рH-моніторингу встановлено, проте сила кореляційного зв'язку менша, ніж із сумарною кількістю балів, що свідчить про перевагу використання з діагностичною метою саме сумарного бала опитувальника для отримання найбільш достовірних результатів.

3. У результаті наведеного дослідження опитувальник GerdQ продемонстрував чутливість - 78,6\%, специфічність 92,9\%. Точність його (діагностична ефективність) згідно з проведеним логіт-регресійним аналізом становила 85,7\%.

\section{Список використаної літератури}

1. Katz PO, Gerson LB, Vela MF. Guidelines for the diagnosis and management of gastroesophageal reflux diseaseю Am. J. Gastroenterol. 2013; 108:308-28

2. DeVault KR, Castell DO. Updated guidelines for the diagnosis and treatment of gastroesophageal reflux disease. Am. J. Gastroenterol. 2005; 100:190-200.

3. Giannini EG, Zentilin P, Dulbecco P. Vigneri S, Scarlata P. Savarino V. Management strategy for patients with gastroesophageal reflux disease: a comparison between empirical treatment with esomeprazole and endoscopy-oriented treatment. Am. J. Gastroenterol. 2008; 103:267-275.

4. Inadomi JM, Jamal R, Murata GH, Hoffman RM, Lavezo LA, Vigil JM, et al. Step-down management of gastroesophageal reflux disease. Gastroenterology. 2001; 121:1095-1100.

5. Badillo R, Dawn F. Diagnosis and treatment of gastroesophageal reflux disease. World J. Gastrointest. Pharmacol. Ther. 2014;5(3): 105-112.

6. Silny J. Intraluminal multiple electric impedance procedure for measurement of gastrointestinal motility. J. Gastrointest. Motil. 1991;3:151-162.

7. Sifrim D, Castell D, Dent J, Kahrilas PJ. Gastro-oesophageal reflux monitoring: review and consensus report on detection and definitions of acid, non-acid, and gas reflux. Gut. 2004;53:1024-1031.

8. Yu Kyung Cho. How to Interpret Esophageal Impedance pH Monitoring. J. Neurogastroenterol. Motil. 2010;16(3):327-330.

9. Vakil N, van Zanten SV, Kahrillas P, Dent J, Jones R. The Montreal definition and classification of GERD: a global evidence-based consensus. Am. J. Gastroenterol. 2006;101:1900-1920.

10. Tytgat GN, Mccoll K, Tack J. Holtmann G, Hunt RH, Malfertheiner $P$, et al. New algorithm for the treatment of gastro-esophageal reflux disease. Aliment. Pharmacol. Ther. 2008;27(3):249-256.

11. Shaheen NJ, Hansen RA, Morgan DR, Gangarosa LM, Ringel Y, Thiny MT, et al. The burden of gastrointestinal and liver diseases. Am. J. Gastroenterol. 2006;101(9):2128-2138

12. Tutuian R, Castell DO. Management of gastroesophageal reflux disease. Am. J. Med. Sci. 2003;326(5):309-318 
13. Маев ИВ, Самсонов АА, Андреев НГ. Симптом изжоги: привычный дискомфорт или серьезная проблема? Фарматека. 2011;10.

14. Pare P, Meyer F, Armstrong D, Pyzyk M, Pericak D, Goeree R. Validation of the GSFQ, a self-administered symptom frequency questionnaire for patients with gastroesophageal reflux disease. Can. J. Gastroenterol. 2003;17(5):307-312.

15. Морозов СМ. Засоби контролю діагностичних якостей психологічних тестів. 1994.

16. Gyawali CP, Kahrilas PJ, Savarino E, Zerbib F, Mion F, Smout AJPM, et al. Modern diagnosis of GERD: the Lyon Consensus. Gut. 2018 Jul;67(7):1351-1362. doi: 10.1136/gutjnl-2017-314722. Epub 2018 Feb 3.

17. Dent J, Vakil $N$, Jones $R$, Bytzer $P$, Schöning U, Halling $K$, et al. Accuracy of the diagnosis of GORD by questionnaire, physicians and a trial of proton pump inhibitor treatment: the Diamond study Gut. 2010;59(6):714-721.

18. Jonasson C1, Moum B. Bang C. Andersen KR. Hatlebakk JG. Randomised clinical trial: a comparison between a GerdQ-based algorithm and an endoscopy-based approach for the diagnosis and initial treatment of GERD. Aliment. Pharmacol. Ther. 2012;35(11):1290-1300.

19. Jones R1, Junghard O, Dent J, Vakil N, Halling K, Wernersson B, et al. Development of the GerdQ, a tool for the diagnosis and management of gastro-oesophageal reflux disease in primary care. Aliment. Pharmacol. Ther. 2009;30(10):1030-1038.

20. Norder Grusell E, Mjörnheim AC, Finizia C, Ruth M, Bergquist H. The diagnostic value of GerdQ in subjects with atypical symptoms of gastro-esophageal reflux disease. Scand J Gastroenterol. 2018 Oct - Nov;53(1011):1165-1170. doi: 10.1080/00365521.2018.1503708.

21. Кайбышева ВО, Кучерявый ЮА, Трухманов АС, Сторонова ОА, Коньков МЮ, Маев ИВ, Ивашкин ВТ. Результаты многоцентрового наблюдательного исследования по применению международного опросника GerdQ для диагностики гастроэзофрагеальной реффлюксной болезни. РЖГГК. 2013;23(5):15-23.

22. Lacy BE, Chehade R, Crowell MD. A prospective study to compare a symptom-based reflux disease questionnaire to 48-h wireless $\mathrm{pH}$ monitoring for the identification of gastroesophageal reflux (revised 2-2611). Am. J. Gastroenterol. 2011;106:1604-1611.

23. Jonasson C, Wernersson B. Hoff DA, Hatlebakk JG. Validation of the GerdQ questionnaire for the diagnosis of gastro-oesophageal reflux disease. Aliment. Pharmacol. Ther. 2013;37:564-572.

24. Suzuki H, Matsuzaki J, Okada S. Hirata K. Fukuhara S. Hibi T. Validation of the GerdQ questionnaire for the management of gastro-esophageal reflux disease in Japan. United European Gastroenterol. J. 2013;1:175-183.

25. Zavala-Gonzales MA, Azamar-Jacome AA, Meixueiro-Daza A, Ramos A, Reyes-Huerta J, Roesch-Dietlen F, et al. Validation and diagnostic usefulness of gastroesophageal reflux disease questionnaire in a primary care level in Mexico. J. Neurogastroenterol. Motil. 2014;20:475-482.

26. Bai Y, Du Y, Zou D, Jin Z, Zhan X, Liet ZS, et al. Gastroesophageal Reflux Disease Questionnaire (GerdQ) in real-world practice: A national multicenter survey on 8,065 patients. J. Gastroenterol. Hepatol. 2013;28:626-631.

27. Teruel-Sánchez-Vegazo C, Faro-Leal V, Muriel-García A, Norberto Mañas Gallardo N. Sensitivity and specificity of the Gastrointestinal Short Form Questionnaire in diagnosis of gastroesophageal reflux disease. Rev. Esp. Enferm. Dig. 2016;108:174-180.

Автори декларують відсутність будь-якого конфрлікту інтересів. 